\title{
Lepra India, Annual Report 1994
}

\section{Foreword}

The British Leprosy Relief Association - LEPRA, is the successor of the British Empire Leprosy Relief Association (BELRA), which has done yeoman service in treatment of leprosy patients in India from 1925, at a time when hardly any organization was willing to undertake work in this most neglected field. The new organization Lepra made a second entry into India in 1987 to support the Government of India in the MDT programme. "Lepra India" was established as a partner to Lepra UK. Having signed the Memorandum of Understanding with the Government of India, Lepra India agreed to follow the guidelines of the Government of India to implement the MDT programme in the allotted endemic districts. The first district to be taken up was Bidar in Karnataka, very soon followed by the twin cities of Hyderabad and Secunderabad and the districts of Karimnagar and Medak in Andhra Pradesh. In all these districts Lepra was to provide funds only for some of the specified items while the government provided the inf rastructure and paid all the salaries.

Request then came from Orissa State to implement the programme in the very difficult hilly tribal areas. A new situation arose here since the State Government was unable to provide the infrastructure, but these areas badly needed help and no one was willing to undertake this arduous task. Lepra India took up the challenge by providing the entire inf rastructure and very systematically conducting the MDT programme incurring a very heavy expenditure. Lepra India is carrying on, on its own, implementation of MDT in the districts of Koraput, Malkangiri, Rayagada and Sonepur. It is also supporting the State Government in the districts of Nowrangpur and Balangir. Thanks to the untiring efforts of all the committed workers, the programme has been very successf ul.

Prevention of deformities is another major task undertaken by Lepra India. This needed training and orientation of all the workers. A detailed plan of action has been prepared and the programme is being introduced gradually in all the areas of operation by Lepra India.

The progress made so far has been very encouraging. Further, a surgical unit has also been established in Muniguda in Rayagada District to make the services available to the patients in the most remote and backward areas. 
Lepra India is also supporting smaller projects under voluntary organizations in the states of Uttar Pradesh, Madhya Pradesh, Andhra Pradesh, Orissa, West Bengal and Kerala. All these projects are engaged in MDT programme.

This report is being presented to outline the activities and achievements in all Lepra India projects. Whatever success that has been achieved is the result of sincere effort of all the dedicated workers through the rank and file. We have full confidence to help the Government of India in its objective of elimination of leprosy in the near future.

Dr K. V. Desikan

Chairman, Lepra Society 


\section{Preface}

As we move towards year 2000, the subject of health is attracting global attention and more so in Third World countries, where diseases such as leprosy/TB/AIDS are prevalent. Leprosy, though receding still remains a threat, especially in India. Of the 2.1 million world's leprosy sufferers, a staggering number, i.e. $64 \%$, are in India.

In the crusade against leprosy Lepra India, a registered charitable voluntary health organization, in partnership with Lepra UK is spearheading a concerted effort to eliminate leprosy from our country.

Lepra India's support scenario includes Government programmes, NGOs and direct programmes. In addition, it runs a modern surgical theatre for the correction of deformities and also funds several leprosy centres for surgical rehabilitation.

Lepra by its sustained campaign and awareness programmes has greatly succeeded in overcoming the stigma and other prejudices attached to leprosy.

Lepra's achievement can be gauged from the fact that since its inception in 1988, it has cured 100,109 by December 1994 . The prevalence rate in areas covered by it has dropped from 7.06 to 1.4 patient per 1000 population. The disability rate in new cases being detected is $4 \cdot 3 \%$ as against $9 \%$ in the beginning.

Though Lepra has achieved significant results, still the momentum must be sustained to reach the goal of a leprosy-free society. Meanwhile emphasis has to be laid on programmes for socioeconomic rehabilitation of patients with disability.

I am pleased to present this project-oriented Annual Report for the year 1994 and I acknowledge that the achievements would not have been possible, but for the full and whole-hearted support from our donor agency Lepra UK. I am personally greatful to the Chairman and Vice-Chairman, Lepra India, Director, Lepra UK and all my colleagues involved in the implementation of MDT at all levels. 


\section{Hyderabad Leprosy Eradication Project (HYLEP)}

The Hyderabad Leprosy Eradication Project covers an urban population of 6 lakhs $(600,000)$ in the old city of Hyderabad. It is one of the 4 projects engaged in antileprosy work in the city. Muslims constitute $60 \%$ of the population. Urdu is the common language. About $44 \%$ of the population live in slums and congested localities.

The project was started on 14 October 1989. The Project area is divided into 8 sectors each of about 75000 population. Each sector is entrusted to one Paramedic. Two non medical supervisors guide the workers in planning and implementation of the programme. A field officer coordinates the day-to-day work. The senior medical officer is over-all incharge of the project. As health education is an important aspect in an urban population, a health educator is also appointed.

To start with, an intensive health education campaign was taken up followed by a house-to-house survey to detect leprosy cases. To overcome the Purdah system, local female auxiliary workers were engaged in the survey.

Drugs are given free to patients at suitably located treatment points near to their homes. In addition 6-weekly clinics are conducted in the local hospitals. This facilitates voluntary reporting of cases and treatment of complications.

Schoolchildren and contacts of patients are examined every year in the project. Rapid enquiry surveys of slums and the general population are undertaken to detect newly developed cases.

Health education is an integral part of the day-to-day work of each paramedic. During a survey flash cards on leprosy are shown to people and the early signs of leprosy are explained. Besides group talks, slide shows, exhibitions and video shows are regularly conducted in slums, schools, youth clubs, factories and service organizations. Antileprosy week is celebrated every year from 30 January to 5 February.

In 1994 a rally was organized on 30 January in which 500 schoolchildren and leprosy workers of voluntary and government units participated. Nine group meetings and 3 programmes of essay and elocution competitions were conducted and prizes were given to the best performers in each event. A Katha-Kavitha and slogan competition on leprosy was organized in which eminent writers and poets participated.

Prevention of disability is an integral part of the programme since 1992. Patients who are at risk are identified, status of each common trunk nerve is recorded in a 
specially designed case card and are followed up at regular intervals. Early nerve damage is detected by testing anaesthesia by graded nylon bristles and motor weakness by voluntary muscle testing. Therapeutic and physiotherapy measures are taken to contain and reverse the nerve damage. Suitable advice is given to patients who report with established anaesthesia and muscular weakness to prevent further worsening of disability in the hands, feet and eyes.

To encourage learning through participation the staff of Hylep get together every week and one among them initiates discussion on a topic allotted to him in advance. The topic is discussed through question and answers and the senior medical officer summarizes important aspects. In addition orientation of field staff is arranged by inviting experts to update their knowledge. A 2-day orientation was arranged for all the staff working in the city on 25 and 26 July 1994.

\section{Balangir Leprosy Eradication Project (BOLEP)}

The Balangir Leprosy Eradication Project covers the entire $4 \cdot 7(470,000)$ population of

\section{General survey:}

\begin{tabular}{lcccccc}
\hline & & \multicolumn{2}{c}{ Population } & \multicolumn{3}{c}{ Cases detected } \\
\cline { 5 - 7 } $\begin{array}{l}\text { Type of } \\
\text { survey }\end{array}$ & Period & Enumerated & Examined & MB & PB & Total \\
\hline House-to-house & $12 / 89$ & $5,61,959$ & $3,55,934$ & 118 & 1068 & 1186 \\
& $10 / 91$ & & & & & \\
Rapid & $11 / 91$ & $5,41,035$ & $3,11,929$ & 45 & 546 & 591 \\
enquiry & $07 / 92$ & & $1,92,389$ & 42 & 294 & 336 \\
House-to-house & $11 / 92$ & $3,65,650$ & & & & \\
\hline
\end{tabular}

School survey during 1994:

\begin{tabular}{lcccccc}
\hline & & & & \multicolumn{3}{c}{ Cases detected } \\
\cline { 4 - 6 } $\begin{array}{l}\text { No. of } \\
\text { schools }\end{array}$ & $\begin{array}{l}\text { Schools } \\
\text { covered }\end{array}$ & $\begin{array}{c}\text { Students } \\
\text { enumerated }\end{array}$ & $\begin{array}{c}\text { Students } \\
\text { examined }\end{array}$ & MB & PB & Total \\
\hline 440 & 145 & 44,135 & 36,012 & - & 48 & 48 \\
\hline
\end{tabular}


MDT performance during 1994:

\begin{tabular}{lrrr}
\hline & MB & PB & Total \\
\hline Cases on record as on 31.12.1993 & 132 & 368 & 500 \\
Cases detected during 1994 & 73 & 394 & 467 \\
Cased deleted as cured during 1994 & 41 & 397 & 438 \\
Cases deleted as left the area, died etc & 18 & 53 & 71 \\
Total cases deleted & 59 & 450 & 509 \\
Balance cases as on 31.12.1994 & 146 & 312 & 458 \\
& & & \\
\hline
\end{tabular}

\section{Important indicators:}

\begin{tabular}{lccccc}
\hline & $\begin{array}{c}\text { Prevalence } \\
\text { rate }\end{array}$ & $\begin{array}{c}\text { New case } \\
\text { detection rate }\end{array}$ & $\begin{array}{c}\text { MB } \\
\text { rate }\end{array}$ & $\begin{array}{c}\text { Child } \\
\text { rate }\end{array}$ & $\begin{array}{c}\text { Disability } \\
\text { rate }\end{array}$ \\
\hline At the beginning & $16 / 10000$ & $2 \cdot 32 / 1000$ & $11 \cdot 29 \%$ & $45 \cdot 8 \%$ & $6 \cdot 5 \%$ \\
As on 31.12.1994 & $7 \cdot 7 / 10000$ & $1 \cdot 09 / 10000$ & $13 \cdot 8 \%$ & $56 \cdot 3 \%$ & $6 \cdot 34 \%$ \\
\hline
\end{tabular}

Patients under POD

Deformities treated

\begin{tabular}{lrrrlrrr}
\hline & MB & PB & Total & & Treated & Improved & Static \\
\hline Active & 80 & 149 & 229 & Claw hand & 71 & 54 & 17 \\
RFT & 55 & 428 & 483 & Lagophthalmos & 6 & 4 & 2 \\
Total & 135 & 577 & 712 & Foot drop & 3 & 2 & 1 \\
& & & & Ulcers & 34 & 6 & 28 \\
\hline
\end{tabular}

the newly formed Subarnapur district in Orissa. The Project was started on 1 April 1990. Subarnapur is one of the most backward districts of the State. It is highly endemic for leprosy. The population is mostly rural and the majority of them are Hindus. Their standard of living is poor and the literacy rate is $24 \%$. Communication facilities are poor.

The River Mahanadi and its tributaries divide the project area of 2284 sq.km into 3 distinct zones. One of the zones Birmaharajpur, can only be reached by ferry as there is no bridge across the Mahanadi. Each zone is supervised by a non medical supervisor. A project officer is overall incharge of organizational and administrative aspects of the 
project. Multidrug therapy is looked after by a medical officer. The Project is divided into 20 sectors; each sector is manned by a paramedic.

Antileprosy work was started in the project by verifying the list of cases handed over by the State Government. The case detection programme was started by conducting a rapid enquiry survey. MDT was started in January 1991; 20 MDT circuits were formed with 10 to 12 drug delivery points for each circuit. A team headed by the medical officer visits each drug delivery point regularly. Patients are brought to the DDPs at the prescribed time by the PMWs, on the treatment day. Preclinic motivation is also done by the PMWs to ensure maximum attendance.

Schoolchildren and contacts of leprosy cases are examined every year. Total population surveys are also repeated at regular intervals for the detection of new cases.

Health education is an integral part of antileprosy work in BOLEP. The project has developed very good relations with the local government officials and the public. Regular meetings are arranged in the villages. Antileprosy day is celebrated every year. Processions and rallies are organized in which NCC, Scouts, Guides and students participate. Essay competitions on leprosy are organized for school and college students.

Effective health education has increased the voluntary reporting of cases $-45 \%$ of cases reported voluntarily during 1994. Another important result of effective health education in the project area is that the local leaders invite the staff to conduct leprosy surveys in their villages. They provide all facilities and cooperate in the detection of cases and their regular treatment.

\section{ECONOMIC EMPOWERMENT OF CURED LEPROSY PATIENTS}

Nineteen cured leprosy patients staying in a self-settled colony at Sonepur were provided with income generating schemes and a dormitory with 20 beds was constructed with the support of the Government and the local NGO.

Income generating schemes such as horticulture and social forestry projects were started with the assistance of the Indian Bank. Manamunda which donated Rs.40,000/-. Also, 9 poultry units costing Rs.13,000/- each will be financed by the Indian Bank.

These schemes will help in reducing the social stigma prevailing in the community and inculcate the habit of earning their livelihood honorably. 
General survey:

\begin{tabular}{|c|c|c|c|c|c|c|}
\hline \multirow{2}{*}{$\begin{array}{l}\text { Type of } \\
\text { survey }\end{array}$} & \multirow[b]{2}{*}{ Period } & \multicolumn{2}{|c|}{ Population } & \multicolumn{3}{|c|}{ Cases detected } \\
\hline & & Enumerated & Examined & MB & PB & Total \\
\hline $\begin{array}{l}\text { Rapid } \\
\text { Survey }\end{array}$ & $\begin{array}{l}05 / 90 \\
12 / 91\end{array}$ & $3,80,124$ & $2,32,872$ & 779 & 3439 & 4218 \\
\hline 1st Mass & $02 / 92$ & $4,26,779$ & $3,78,620$ & 627 & 1866 & 2493 \\
\hline Survey & $03 / 94$ & & & & & \\
\hline 2nd Mass & $04 / 94$ & $2,50,298$ & $1,95,459$ & 260 & 724 & 984 \\
\hline Survey & $12 / 94$ & & & & & \\
\hline
\end{tabular}

School survey during 1994:

\begin{tabular}{lcccccc}
\hline & & & & \multicolumn{3}{c}{ Cases detected } \\
\cline { 5 - 7 } $\begin{array}{l}\text { No. of } \\
\text { schools }\end{array}$ & $\begin{array}{l}\text { Schools } \\
\text { covered }\end{array}$ & $\begin{array}{c}\text { Students } \\
\text { enumerated }\end{array}$ & $\begin{array}{c}\text { Students } \\
\text { examined }\end{array}$ & MB & PB & Total \\
\hline 782 & 728 & 68,443 & 45,889 & 6 & 79 & 85 \\
\hline
\end{tabular}

MDT performance during 1994:

\section{Important indicators:}

\begin{tabular}{lcccc}
\hline & $\begin{array}{c}\text { Prevalence } \\
\text { rate }\end{array}$ & $\begin{array}{c}\text { MB } \\
\text { rate }\end{array}$ & $\begin{array}{c}\text { Child } \\
\text { rate }\end{array}$ & $\begin{array}{c}\text { Disability } \\
\text { rate }\end{array}$ \\
\hline At the beginning & $228 / 10000$ & $26 \cdot 6 \%$ & $20 \cdot 7 \%$ & $7 \cdot 9 \%$ \\
As on 31.12.1994 & $47 / 10000$ & $39 \cdot 7 \%$ & $23 \cdot 9 \%$ & $7.2 \%$ \\
\hline
\end{tabular}




\section{Koraput Leprosy Eradication Project (KORALEP)}

The Koraput Leprosy Eradication Project (KORALEP) covers the two newly formed districts of Koraput and Malkangiri with a population of 14,76,774. The area is vast $(14,649$ sq. $\mathrm{km})$ and the terrain is hilly and difficult. Communications are meagre. There are 6096 villages in the Project. Most of them are small and scattered; $53 \%$ of the population is tribal and the literacy rate is $18 \%$.

Difficult terrain, scattered small villages, and illiterate tribal population with traditional sociocultural life styles, make the task of eradication of leprosy in Koraput a challenging one.

The project is designed and supervised by a field consultant. A senior medical officer is in-charge of the programme. He is assisted in supervision by a field officer. Three zones have been formed with a NMS responsible for each zone. The entire area is divided into 30 sectors. Each sector is looked after by one paramedic who is responsible for 50,000 population. Locally trained village voluntary workers who are fluent in the local dialect assist the paramedic in detection and motivation of cases for treatment.

Initially a rapid enquiry survey was conducted to detect leprosy cases followed by house-to-house and total population surveys. School and contact surveys are done annually. All cases detected are put on MDT. The project area is divided into 25 MDT circuits with 184 treatment points, which are located in the PHCs, schools, Panchayat Offices and community halls.

Health education is given importance in the project. During the survey, flash cards are shown to people to explain signs and symptoms of leprosy. Group talks, slide shows, exhibitions and video programmes are also conducted regularly.

During 1994, 12 group talks, 24 slide shows, 2 video shows and 4 exhibitions were organized in the project area. There has been a steady increase in the percentage of voluntary reporting of cases from $23 \%$ in 1992 to $40 \%$ in 1994.

A community health programme was started in August 1994 with the objective of providing treatment facilities for minor ailments initially involving local tribal youth as health volunteers and to enable them to gradually function as a vital link between the people and health workers at primary health centres. A training programme of 3 weeks for 13 tribal educated youths was organized with the help of 11 specialists from the headquarters hospital in Koraput. A health survey in 7 villages was completed. A weekly clinic was also started in October 1994 for minor ailments. 
A 6-bedded health care centre was established on 8 October 1994 at Koraput. The Centre is intended for temporary hospitalization of leprosy cases with reactions and other complications. During the 3-month period to the end of December 1994, 15 patients were admitted in this centre; 7 cases for reactions, 2 for neuritis, 5 for trophic ulcers and 1 for intercurrent infection.

\section{General survey:}

\begin{tabular}{lcccccc}
\hline & & \multicolumn{2}{c}{} & & \multicolumn{3}{c}{ Cases detected } \\
\cline { 5 - 7 } $\begin{array}{l}\text { Type of } \\
\text { survey }\end{array}$ & Period & Enumerated & Examined & MB & PB & Total \\
\hline Rapid & $11 / 91$ & $13,75,376$ & $7,84,090$ & 848 & 1852 & 2700 \\
Enquiry & $10 / 93$ & & & & & \\
House-to-house & $11 / 93$ & $6,75,287$ & $5,11,119$ & 246 & 1202 & 1448 \\
& $12 / 94$ & & & & &
\end{tabular}

School survey during 1994:

\begin{tabular}{lccccc}
\hline & & & \multicolumn{3}{c}{ Cases detected } \\
\cline { 4 - 6 } $\begin{array}{l}\text { No. of } \\
\text { schools }\end{array}$ & $\begin{array}{l}\text { Schools } \\
\text { covered }\end{array}$ & $\begin{array}{c}\text { Students } \\
\text { examined }\end{array}$ & MB & PB & Total \\
\hline 2650 & - & 23,888 & 0 & 35 & 35 \\
\hline
\end{tabular}

MDT performance during 1994:

\begin{tabular}{lrrr}
\hline & MB & PB & Total \\
\hline Cases on record as on 31.12.1993 & 1166 & 1503 & 2669 \\
Cases detected during 1994 & 407 & 1626 & 2033 \\
Cased deleted as cured during the year & 78 & 1613 & 1691 \\
Cases deleted as left the area, died etc & 48 & 38 & 86 \\
Total cases deleted & 126 & 1651 & 1777 \\
Balance cases as on 31.12.1994 & 1447 & 1478 & 2925 \\
\hline
\end{tabular}


Important indicators:

\begin{tabular}{lcccc}
\hline & $\begin{array}{c}\text { Prevalence } \\
\text { rate }\end{array}$ & $\begin{array}{c}\text { MB } \\
\text { rate }\end{array}$ & $\begin{array}{c}\text { Child } \\
\text { rate }\end{array}$ & $\begin{array}{c}\text { Disability } \\
\text { rate }\end{array}$ \\
\hline At the beginning & $74 / 10000$ & $36 \%$ & $17 \%$ & $8 \cdot 7 \%$ \\
As on 31.12.1994 & $20 / 10000$ & $20 \%$ & $19 \%$ & $5 \cdot 1 \%$ \\
\hline
\end{tabular}

\section{Lepra's support to government MDT districts:}

Lepra India provides financial, logistic and technical support for the implementation of MDT programmes in 5 districts in 3 states of India. This is in persuance of an agreement signed in 1989 between Lepra India and the Ministry of Health, Government of India. The districts supported as per this agreement are Bidar in Karnataka State. Karimnagar and Medak in Andhra Pradesh and Balangir and Nabarangpur in Orissa. Lepra India provides to each district:

The entire requirement of antileprosy drugs for all patients;

3 jeeps, microscopes, typewriters, duplicating machine and audiovisual aids;

the purchase of emergency drugs;

the total cost of POL and maintenance for vehicles supplied by Lepra and parts for Government vehicles under NLEP;

MDT incentives to all the cadres of staff as per the Government of India guidelines;

the welfare needs of patients including a supply of MCR footwear, spectacles, and supplementary diet for inpatients;

the printing of case cards, purchase of stationery and health education material;

funds for training and orientation to staff;

technical consultation services to all the 5 districts.

A brief note on each district follows:

BIDAR

Bidar is one of the backward districts of Karnataka State. It sits as a crown on the state 
map. No wonder it is the jewel in the crown of the state as far as the implementation of MDT is concerned.

It has a population of $12,55,799$. MDT was started in the district in October, 1988 with the support of Lepra India. As an exception Lepra India provided all 5 jeeps to the district to implement MDT. In addition to the successful implementation of MDT the district administration also contributed significantly towards rehabilitation of leprosy patients such as:

Economic rehabilitation: 21 leprosy patients were helped to secure government jobs; bank loans were arranged for 47 leprosy patients for income generating schemes.

Social acceptance: marriages of 7 cured leprosy patients were performed.

Physical rehabilitation: 66 eye operations were conducted; 100 pairs of spectacles and 108 pairs of MCR footwear were provided.

Lepra India also conducted orientation for NLEP staff and all medical officers of PHCs in the district.

MDT performance during 1994:

\begin{tabular}{lrrr}
\hline & MB & PB & Total \\
\hline Cases on record as on 31.12.1993 & 463 & 911 & 1374 \\
Cases on record during 1994 & 177 & 1263 & 1440 \\
Cased deleted as cured & 232 & 1488 & 1720 \\
Cases deleted otherwise & 25 & 34 & 59 \\
Balance of cases as on 31.12.1994 & 383 & 652 & 1035 \\
Prevalence rate as on 31.12.94 .......... & & & \\
& & & \\
\end{tabular}

\section{KARIMNAGAR}

Karimnagar was one of the hyper-endemic districts for leprosy. GOI sanctioned MDT for the district in 1988. After a rapid enquiry survey and screening, MDT was started in the district in 1989. Due to various administrative reasons MDT could not be implemented in all the units simultaneously. However, by 1991 the entire district was covered. Although the prevalence rate has shown a marked reduction, the new case detection rate has not shown any appreciable decline. After MDT 31656 cases have been deleted from treatment. 
MDT performance during 1994:

\begin{tabular}{lrrr}
\hline & MB & PB & Total \\
\hline Cases on record on 31.12.93 & 1433 & 2556 & 3989 \\
Cases recorded during the year & 511 & 2881 & 3392 \\
Cased deleted as cured & 709 & 3965 & 4674 \\
Cases deleted otherwise & 164 & 199 & 363 \\
Balance of cases as on 31.12.94 & 1071 & 1273 & 2344 \\
Prevalence rate as on 31.12.94 .........7.7/10000 & \\
\hline
\end{tabular}

Orientation of staff was taken up in the district, once for updating the knowledge of the field staff in leprosy, and the second time for prevention of deformity. One of the units of Huzurabad has also started POD for cases on treatment.

MEDAK

Medak is the neighbouring district to Hyderabad and also to Bidar. MDT was sanctioned for the district in 1989. Initially, GOI provided funds for MDT but later Lepra India was identified as the donor agency. Mr William Peters, Chairman of Lepra UK inaugurated MDT in the town of Gajwel in August 1989. MDT was started in all the 4 units of the district between January and April 1990. MDT implementation in the district was satisfactory.

This District did not have the required PMWs, which was affecting the implementation of MDT. Lepra India, therefore, agreed to support 15 daily wage workers from 1989 to 1994 to enable the district to start MDT on time in Narayankhed unit.

MDT performance during 1994:

\begin{tabular}{lrrr}
\hline & MB & PB & Total \\
\hline Cases on record on 31.12.93 & 916 & 915 & 1831 \\
Cases recorded during 1994 & 326 & 1017 & 1343 \\
Cased deleted as cured & 480 & 1184 & 1664 \\
Cases deleted otherwise & 121 & 128 & 249 \\
Balance of cases as on 31.12.94 & 641 & 620 & 1261 \\
Prevalence rate as on 31.12.94 ........ $\ldots$ & $5 \cdot 6 / 10,000$ & \\
& & & \\
\hline
\end{tabular}


BALANGIR

MDT implementation in the Balangir district of Orissa started in 1989.

MDT implementation in Balangir is not as smooth as in other districts due to certain administrative problems. Ten out of 20 sectors in the Patangarh unit are yet to start MDT, as the posts of PMWs in those sectors remain vacant. In 2 sectors of the Titlagarh unit, MDT is not taken up as these sectors are inaccessible during the monsoon.

Orientation training to field staff of the district was conducted during the year. Consultancy services were also provided by Lepra.

MDT performance during 1994:

\begin{tabular}{lrrr}
\hline & MB & PB & Total \\
\hline Cases on record on 31.12.93 & 3651 & 2669 & 6320 \\
Cases recorded during the year & 757 & 2593 & 3350 \\
Cased deleted as cured & 1947 & 3242 & 5189 \\
Cases deleted otherwise & 726 & 352 & 1078 \\
Balance of cases as on 31.12.94 & 1735 & 1668 & 3403 \\
Prevalence rate as on 31.12.94 ........ 28 & & \\
\hline
\end{tabular}

\section{NABARANGPUR}

Nabarangpur is one of the four districts carved out of the old Koraput district. The other three districts, i.e. Koraput and Malkangiri are covered by Lepra India and Rayagada is covered by The Leprosy Mission and Hoina Leprosy Research Trust with the assistance of Lepra India.

MDT was taken up in the Nabarangpur district in January 1993. The Government has not yet sanctioned a complete infrastructure in the district. 17 out of 40 posts of paramedical workers are vacant. Therefore, MDT coverage is only partial and has not yet gained momentum because of various administrative problems.

\section{Lepra's Support to Non-Governmental Organizations}

Since its inception, Lepra India has been extending financial assistance to voluntary leprosy organizations engaged in the SET method of work. 
MDT performance during 1994:

\begin{tabular}{lrrr}
\hline & MB & PB & Total \\
\hline Cases on record on 31.12.93 & 870 & 2379 & 3249 \\
Cases recorded during the year & 288 & 732 & 1020 \\
Cased deleted as cured & 18 & 1094 & 1112 \\
Cases deleted otherwise & 123 & 1457 & 1580 \\
Balance of cases as on 31.12.94 & 1017 & 560 & 1577 \\
Prevalence rate as on 31.12.94 . . . . . . . 20 20/10000 & \\
\hline
\end{tabular}

During the last 6 years, Lepra India supported ten voluntary leprosy organizations such as grants to meet expenses towards salaries, maintenance, administration and for creating infrastructure.

A brief description of each voluntary organization is given below. Particular area/ population covered, and achievements after MDT implementation are given in Annexture I.

ANDHRA PRADESH:

\section{Grama Nava Nirmana Samithi, Hyderabad}

Grama Nava Nirmana Samithi is one of the 4 projects engaged in antileprosy work in the twin cities of Secunderabad and Hyderabad. The project was started in October 1985. It covers 13 wards of the Municipal Corporation of Hyderabad. The population is predominantly Hindu.

An initial total population survey, with emphasis on maximum coverage in slums, was conducted. MDT was introduced to the project at the beginning. The project was divided into 15 MDT circuits having 71 treatment points. Due to the reduction in the caseload, there are 44 treatment points now; 1 circuit is visited each day. The project has a well-equipped physiotherapy unit. The staff of the project have been trained in the POD programme by the medical consultant and senior medical officer of Lepra India.

The project also has a footwear unit where MCR footwear and special shoes for cases with footdrop and other foot complications are manufactured. The project supplies the footwear requirement of institutions at Hyderabad and adjoining districts. 


\section{Hyderabad Leprosy Control and Health Society, Hyderabad}

The society was started in 1985 and registered with the Government in 1986. Ward No. 18 of the old city of Hyderabad was allotted for leprosy work in 1989. Until then, the organization was mainly organizing medical camps and health education programmes and referring detected cases of leprosy to Osmania General Hospital.

The organization conducted a total population survey in the allotted area examining $83 \%$ of the population. All cases detected were on monotherapy until September 1992. MDT was started in September 1992, Lepra India started supporting the project in January 1993.

\section{Prema Samajam, Vizianagaram}

Prema Samajam is a voluntary organization registered in 1950 to provide care for the aged, needy and disabled. It is located in the urban area of Vizianagaram.

Leprosy Control Programme was started in February 84 in 36 wards of Vizianagaram town. A total population survey was undertaken in the project area before commencement of MDT in June 1984.

The leprosy control project was run by the organization from its own resources and the support extended by OXFAM until 1986. Subsequently it was funded by Lepra.

The project has a well-equipped physiotherapy unit, a weaving unit in which training-cum-production facilities are available. The weaving unit produces bandage cloth which is sold to voluntary organizations in Vizianagaram and adjacent districts.

The Organization has two in-patient wards of 5 beds each for male and females patients.

BIHAR

\section{Gandhi Kusht Nivaran Pratisthan, Bhabua}

Gandhi Kusht Nivaran Pratisthan was established in 1960 and was running 4 SET units covering a population of around 8 lakhs $(800,000)$. In 1989 , the project had to be closed down because of an acute financial crisis. About 8000 patients were under MDT at the time of closure of the Project. Lepra India started funding this programme in January 1993 initially with a population of 4 lakhs $(400,000)$. 
The area is backward, partly hilly and has very poor communication and transport facilities. A rapid enquiry survey was conducted before undertaking MDT. The area is highly endemic for leprosy with a prevalence rate of 11 per 1000, before commencement of MDT. The Project is divided into 8 MDT sectors for supervised administration of MDT.

The Project has a temporary hospitalization ward, a physiotherapy unit, an infirmary for crippled and dependent patients and vocational training unit with workcum-production facility to provide training to needy patients in suitable trades and crafts.

KERALA

Paul Chittilapilly Memoral Leprosy Control Project, Kalladikode

The PCM Leprosy Project started functioning from February 87. It is a project of the congregation of Samaritan Sisters, founded for the cause of leprosy patients.

The Project was covering a population of one lakh $(100,000)$ from 1987 to 1991. From 1992, an additional population of 1.5 lakhs $(150,000)$ was allotted to the project by the State Government. The area is hilly and the terrain is difficult.

The Project concurrently runs general health programmes along with leprosy control activity. A hospital building was constructed with the financial assistance of Lepra India where general and leprosy patients are admitted without any discrimination.

The Project has completed surveys in 7 out of 11 panchayats. MDT was started in the Project in 1988. The treatment points are fixed in Govt. hospitals and family welfare centres with a view to orient the public and health staff with leprosy work. Health education activity is regularly carried out for different groups. The project has all necessary educational equipment and material.

MADHYA PRADESH

St Joseph's Leprosy Centre, Deepalay, Sanawad

St Joseph's Convent is run by the sisters of St Joseph of St Trudpert whose Regional House is at Bijalpur, Indore. The sisters run a school and maternity hospital in Sanawad. 
St Joseph's Leprosy Centre started its survey work in May 1992. The SET pattern of work was started in February 1993. The Project covers a population of two lakhs $(200,000)$ in Khargone district in Western Madhya Pradesh.

ORISSA

Hoina Leprosy Research Trust, Muniguda

The Hoina Leprosy Research Trust was established in 1986. The Trust was allotted 3 blocks in 1987 and another 3 blocks in 1991 by the State Government.

The Trust covers the entire sub-division of Gunupur of Rayagada district. The area is hilly and communication facilities are poor in the rainy season because of several rivers and rivulets. The population is predominantly tribal.

In the preparatory stage, a total population survey was conducted in which $80 \%$ of the population was examined. The area is organized into 9 MDT sectors for treatment of patients.

A surgical unit funded by Lepra India, has been established at the project headquarters, for undertaking reconstructive surgery for various deformities due to leprosy. The unit started functioning in July 1994. It caters to the needs of Western Orissa, Southern Madhya Pradesh and the Northern districts of Andhra Pradesh bordering Orissa. The unit consists of 10 beds and operations are done free of charge.

The Leprosy Mission, Rayagada

The SET unit of the Leprosy Mission at Rayagada covers the Rayagada sub-division of the Rayagada district, which was earlier a part of the Koraput district. Rayagada town is also covered by The Leprosy Mission.

An MDT Programme was implemented by the project in November, 92. Lepra India extends financial support to the organization only for MDT implementation which includes antileprosy drugs, and incentives to staff.

UTTAR PRADESH

Trinity Association for Social Service, Kopia

This organization was established in 1983 to provide medicosocial services to the poor, 
destitutes and aged. Regular leprosy work has been undertaken since January 93. The Project area is surrounded and criss-crossed by rivers and is flooded every year during the rainy season. The transportation facilities are also poor. The population is rural and the literacy rate is $35 \%$ in males and $15 \%$ in females. A total population survey was carried out for the detection of cases before the commencement of MDT. The area has been organized into 10 sectors with one PMW per sector. MDT was started in 1993 in all the sectors.

WEST BENGAL

Gandhi Memorial Leprosy Foundation, Calcutta

The Calcutta Urban Leprosy Project of Gandhi Memorial Leprosy Foundation was established in December 1989. The Project has been covering 9 corporation wards of Calcutta.

House-to-house surveys and explanations with the use of flash cards where people were reluctant to be examined, were carried out, so that persons with suspected signs could report voluntarily. MDT was started simultaneously.

Lepra's support to this Project was completed in 1994. 
Achievements of voluntary organizations supported by Lepra India during 1994

Annexure I

\begin{tabular}{|c|c|c|c|c|c|c|c|c|c|c|c|c|c|c|c|c|c|}
\hline \multirow{2}{*}{$\begin{array}{l}\text { Names of } \\
\text { projects }\end{array}$} & \multirow{2}{*}{$\begin{array}{c}\text { Area } \\
\text { (sq. km) }\end{array}$} & \multirow[b]{2}{*}{ Population } & \multirow{2}{*}{$\begin{array}{l}\text { Year of } \\
\text { starting }\end{array}$} & \multicolumn{3}{|c|}{$\begin{array}{l}\text { Total cases } \\
\text { recorded till ’94 }\end{array}$} & \multirow[b]{2}{*}{ MB } & \multirow{2}{*}{$\begin{array}{l}\text { RFT } \\
\text { PB }\end{array}$} & \multicolumn{2}{|c|}{ Deletions } & \multirow{2}{*}{$\begin{array}{l}\text { Others } \\
\text { PB }\end{array}$} & \multirow[b]{2}{*}{ Total } & \multicolumn{3}{|c|}{$\begin{array}{c}\text { Balance cases } \\
\text { as on } 31.12 .94\end{array}$} & \multicolumn{2}{|c|}{$\begin{array}{c}\text { Prevalence rate } \\
\text { (per 1000) }\end{array}$} \\
\hline & & & & $\mathrm{MB}$ & PB & Total & & & Total & $\mathrm{MB}$ & & & $\mathrm{MB}$ & $\mathrm{PB}$ & Total & MDT Beg. & in '94 \\
\hline GNNS & 50 & 933605 & 1987 & 734 & 4099 & 4833 & 368 & 3147 & 3515 & 243 & 739 & 982 & 123 & 213 & 336 & $4 \cdot 4$ & $0 \cdot 35$ \\
\hline HLCHS & 15 & 245132 & 1992 & 133 & 619 & 752 & 38 & 452 & 490 & 45 & 74 & 119 & 50 & 93 & 143 & $1 \cdot 1$ & $0 \cdot 65$ \\
\hline PS & 28 & 115209 & 1984 & 264 & 1315 & 1579 & 188 & 1185 & 1373 & 58 & 77 & 135 & 18 & 53 & 71 & $2 \cdot 5$ & $0 \cdot 60$ \\
\hline GKNP & 1206 & 400708 & 1993 & 368 & 1586 & 1954 & 34 & 906 & 940 & 71 & 370 & 441 & 263 & 310 & 573 & $5 \cdot 7$ & $1 \cdot 40$ \\
\hline PCM & 219 & 289643 & 1987 & 324 & 685 & 1009 & 197 & 532 & 729 & 60 & 114 & 174 & 67 & 39 & 106 & $2 \cdot 1$ & $0 \cdot 36$ \\
\hline SJC & 655 & 20000 & 1992 & 430 & 417 & 847 & 98 & 103 & 201 & 122 & 104 & 226 & 210 & 210 & 420 & $2 \cdot 1$ & $2 \cdot 10$ \\
\hline HOINA & 4500 & 379252 & 1987 & 1084 & 2494 & 3578 & 493 & 1904 & 2397 & 160 & 199 & 359 & 431 & 391 & 822 & $8 \cdot 0$ & $2 \cdot 36$ \\
\hline TLM & 3085 & 335347 & 1992 & 514 & 786 & 1300 & 49 & 366 & 415 & 46 & 46 & 92 & 419 & 374 & 793 & $7 \cdot 0$ & $2 \cdot 40$ \\
\hline TAFSS & 521 & 351118 & 1993 & 330 & 971 & 1301 & 47 & 584 & 631 & 8 & 6 & 14 & 275 & 381 & 656 & $5 \cdot 1$ & 1.80 \\
\hline GMLF & N.A. & 353274 & 1989 & 100 & 345 & 445 & 14 & 156 & 170 & 15 & 34 & 49 & 71 & 155 & 226 & $0 \cdot 9$ & $0 \cdot 06$ \\
\hline Total & & & & 4281 & 13317 & 17598 & 1526 & 9335 & 10861 & 828 & 1763 & 2591 & 1927 & 2219 & 4146 & & \\
\hline
\end{tabular}


Anexure II Summary of achievement of all Lepra projects

\begin{tabular}{ll} 
\\
\\
\\
\\
rate $(000)$ \\
\\
\\
& 1994 \\
\hline & $0 \cdot 70$ \\
6.70 \\
$2 \cdot 00$ \\
$0 \cdot 80$ \\
$0 \cdot 60$ \\
$0 \cdot 80$ \\
$2 \cdot 80$ \\
$2 \cdot 00$ \\
$0 \cdot 35$ \\
$0 \cdot 60$ \\
$0 \cdot 60$ \\
$1 \cdot 40$ \\
0.36 \\
$2 \cdot 10$ \\
$2 \cdot 36$ \\
$2 \cdot 40$ \\
$1 \cdot 80$ \\
$0 \cdot 06$ \\
- \\
\\
\end{tabular}

